УДК 342.9

DOI https://doi.org/10.32844/2618-1258.2019.5-1.34

КВАШИН В.Ю.

\title{
ДО ХАРАКТЕРИСТИКИ ПРИНЦИПІВ ЗАБЕЗПЕЧЕННЯ ПРАВ ГРОМАДЯН МИТНИМИ ОРГАНАМИ УКРАЇНИ
}

У статті на основі аналізу наукових праць вчених та норм чинного законодавства визначено та охарактеризовано принципи забезпечення прав громадян митними органами України. Надано авторське визначення поняття «принципи забезпечення прав громадян митними органами України», до кола відповідних засад віднесено: принцип верховенства права; принцип законності; принцип рівності та недискримінації; принцип гуманізму; принцип взаємодії; принцип гласності та прозорості. 3'ясовано, що принципи забезпечення прав громадян митними органами України - це вихідні, об'єктивні, закономірні положення, керівні ідеї правової діяльності Державної митної служби України в сфері дотримання, забезпечення реалізації та захисту прав громадянина та людини в рамках здійснення митної справи. Доведено, що проблематика правових принципів зображує питання щодо ідейності права, його соціального походження та призначення, внутрішнього ядра. В найбільш стандартизованому вигляді, виходячи з наведених вище наукових підходів, принципи права - це основоположні, керівні, рушійні ідеї права та правового регулювання суспільних відносин, виражені та закріплені в нормах законодавчого матеріалу. Наголошено, що принцип рівності та недискримінації втілено в багатьох положеннях чинного законодавства та Конституції. Відповідно до нього будь-якій людині та громадянину гарантується рівність перед законом та державою, а також неприпустимість обмеження прав за особистими ознаками, як-от: колір шкіри, віра, стать, релігійні переконання тощо. Визначено, що принципи права об'єктивно зумовлені характером суспільних відносин, економічною й політичною структурою суспільства й відображають об'єктивні закономірності суспільного розвитку. В основних ідеях предметом відображення є система суспільних відносин й передусім іiі головні ланки - відносини власності й влади в суспільстві. Ці ідеї відображають уявлення про належне саме з точки зору правової організації суспільних відносин. Зроблено висновок, що на законодавчому рівні та у правовому полі існує велика кількість принципів, пов'язаних із митною справою, діяльністю митних органів або правовим регулювання суспільних відносин в країні загалом.

Ключові слова: принции, принциии права, забезпечення прав громадян, митні органи України, загальноправові принщчипи, спеціальні принциии.

In the article, on the basis of the analysis of scientific works of scientists and norms of the current legislation of Ukraine, the principles of ensuring the rights of citizens by the customs bodies of Ukraine are defined and characterized. The author defines the concept of "principles of securing the rights of citizens by the customs authorities of Ukraine", the relevant principles include: the principle of the rule of law; the principle of legality; the principle of equality and non-discrimination; the principle of humanism; principle of interaction; the principle of transparency and transparency. It has been found out that the principles of ensuring the rights of citizens by the customs authorities of Ukraine are the initial, objective, legal provisions, guiding ideas of the legal activity of the State Customs Service of Ukraine in the sphere of observance, ensuring the realization and protection of the rights of the citizen and the person in the course of customs affairs. It is proved that the problems of legal principles portray the question of the ideology of law, its social origin and purpose, the inner core. In the most standardized form, based on the above scientific approaches, the principles of law are fundamental, guiding, driving ideas of law and legal regulation of social relations, expressed and enshrined in the rules

( С КВАШИН В.Ю. - здобувач (Науково-дослідний інститут публічного права) 
of legislative material. It is emphasized that the principle of equality and non-discrimination is embodied in many provisions of the current legislation and the Constitution. According to him, any person and citizen is guaranteed equality before the law and the state, as well as the inadmissibility of restriction of rights on personal grounds, such as skin color, faith, gender, religious beliefs, etc. It is determined that the principles of law are objectively conditioned by the nature of social relations, the economic and political structure of society and reflect the objective patterns of social development. In the main ideas, the subject of reflection is the system of social relations, and above all its main links - the relations of property and power in society. These ideas reflect perceptions of what is proper in terms of the legal organization of public relations. It is concluded that at the legislative level and in the legal field, there are a large number of principles related to customs, the activities of customs authorities or the legal regulation of public relations in the country as a whole.

Key words: principle, principles of law, protection of citizens'rights, customs authorities of Ukraine, general principles, special principles.

Вступ. Гуманістичні ідеї, закладені на теренах розвитку нашої держави як незалежної, суверенної країни, викликали необхідність підтримки в будь-яких сферах владної діяльності ряду ідеалістичних постулатів, одним з яких є права та свободи людини та громадянина. Ступінь їх розвитку та додержання показує сучасність, соціальну спрямованість держави. Однак, щоб цей ступінь мав високий показник, права та свободи людини і громадянина повинні належним чином забезпечуватись у роботі органів державної влади, зокрема митних. Втім, як і будь-яка інша діяльність, робота митних органів України має будуватись на певних засадах, тобто принципах, що мають значення відправних начал для будь-якого правового явища.

Стан дослідження. Окремі проблемні питання діяльності митних органів щодо забезпечення прав громадян у своїх наукових працях розглядали Р.З. Лівшиц, О.А. Коваль, К.Ю. Мельник, В.Т. Комзюк, Л.В. Мелех, В.В. Ладиченко, В.В. Король, Ю.О. Загуменна, В.Ю. Кобринський, А.Т. Комзюк, А.С. Крупник, Б.Я. Кузняк, В.А. Свічкарь, І.В. Кушнарьов, О.Я. Стойко, В.В. Ченцов та багато інших. Однак, незважаючи на чималу кількість наукових розробок, у юридичній літературі відсутні комплексні дослідження, присвячені принципам забезпечення прав громадян митними органами України.

Постановка завдання. Мета статті - визначити та надати характеристику принципам забезпечення прав громадян митними органами України.

Результати дослідження. Термін «принцип» походить від латинського “principium” та має такі значення: основа, початок, фундамент, правило, підстава, від якого не відступають; основне вихідне положення якої-небудь теорії, навчання; основа устрою, дії якого-небудь механізму, приладу, установки [1, с. 431]. Неодноманітне визначення терміну «принцип» також є у філософії, а саме: в онтології принципи - це першооснова, початок світу (поняття принципу схоже 3 поняттям субстанції); у гносеології і методології принцип - це складна, концентрована форма знання, яка акумулює в собі основний напрям дослідження, його «дух». Так, І. Кант розрізняв принцип «регулятивний», який використовується Розумом, що виконує направляючу, стимулюючу роль у дослідженні, і принцип «конститутивний», який використовується Розумом і $є$ підставою для упорядкування світу феноменів; в етиці синонімом терміну «принцип» $є$ «максима», що розглядається як основоположення волі [2, с. 314]. Отже, в загальному етимологічному значенні принцип постає чимось головним, ідеєю побудови, рушійною основою, закономірністю якогось явища, механізму, організації тощо.

На цей час теорія про принципи розкинулась ще більше у правовій науці, про що свідчить велика кількість визначень цього поняття. Наприклад, Р.З. Лівшиц вказує: «Принципи характеризують всю правову матерію - i ідеї, і норми, і відносини - і надають їй логічності, послідовності, збалансованості. У принципах права ніби синтезується світовий досвід розвитку права, досвід цивілізації. Принципи - ніби «сухий залишок» найбагатшої правової матерії, іiі суть, звільнена від конкретики і деталей. Принципи відіграють роль орієнтирів у формуванні права. Еволюція права йде від ідей до норм, потім через реалізацію норм до суспільної практики. І ось, починаючи з появи ідеї, а ідея дуже часто формується у вигляді правового принципу, принцип визначає розвиток права» [3]. Схоже визначення формує О.Л. Вязов: «Принцип - це перш за все ідея. Але не тільки ідея. Це передусім ідеї, але також норми і відносини. Постають елементами людської культури, оскільки вироблені протягом всієї історії розвитку людського 
суспільства. Це один із засобів, що дозволяє зберегти баланс між об'єктивною необхідністю суспільного розвитку і суб'єктивним розсудом законодавця» [4, с. 16]. А.М. Васильєв тлумачить принципи права як основні ідеї, які являються відправними в законодавчій діяльності, отримують своє вираження і конкретизуються у змісті правових норм, виступають як спрямовуючі установки під час реалізації норм та втілюються у правопорядку [5, с. 270]. Широке обгрунтування принципів права пропонує О.А. Коваль, на думку якого принципи права необхідно виводити не з ідеологічних категорій, а з правової матерії загалом. Визнаючи право системою суспільного впорядкування, як шлях й засіб запобігання й вирішення суперечностей, необхідно таким же чином конструювати й принципи права. Вони охоплюють усю правову матерію і ідеї, і норми, і правовідносини - надають їй логічності, послідовності й збалансованості. У принципах права синтезується світовий досвід розвитку права, досвід цивілізації. Принципи - це, так би мовити, «сухий залишок» усієї правової матерії, ії зміст, вільний від конкретики. Ідеологічною основою принципів права $є$ ідеї права, в яких втілюється розуміння його сутності і соціальної ролі. Ідеї права - це сфера правосвідомості, в тому числі юридичної науки. Ідеї права можуть передувати формуванню цієї правової системи, можуть тим чи іншим чином знайти своє відображення в нормах і принципах діючого права. Принципи права об'єктивно зумовлені характером суспільних відносин, економічною й політичною структурою суспільства й відображають об'єктивні закономірності суспільного розвитку. В основних ідеях предметом відображення є система суспільних відносин й передусім іії головні ланки - відносини власності й влади в суспільстві. Ці ідеї відображають уявлення про належне саме 3 погляду правової організації суспільних відносин. Право, правова дійсність, правова матерія виступають у трьох проявах. Цю єдність складають, по-перше, правосвідомість, ідеї, уявлення про право, по-друге, правові норми, по-третє, суспільні відносини, що зумовлюють виникнення норми права й своєю чергою отримують вплив цих норм. Таким чином, якщо йдеться про вихідні ідеї, сутність права, то істотно, що вона, по-перше, присутня в усіх проявах правової дійсності й, по-друге, виникає й формулюється спочатку в правосвідомості й далі отримує законодавче закріплення. Як і будь-якому об'єкту, створеному людством, йому передували певні ідеї, уявлення про нього, висувалися певні принципи, на яких він повинен бути побудований, й таке інше [6].

Таким чином, проблематика правових принципів зображує питання щодо ідейності права, його соціального походження та призначення, внутрішнього ядра. В найбільш стандартизованому вигляді, з огляду на наведені вище наукові підходи, принципи права - це основоположні, керівні, рушійні ідеї права та правового регулювання суспільних відносин, виражені та закріплені в нормах законодавчого матеріалу. При цьому правові принципи багатоманітні, у зв'язку із чим поділяються на загальні керівні ідеї та спеціальні. Так, загальні принципи - це, так би мовити, рушійні начала правової реальності загалом. Вони формують джерело правової системи, iii найвизначніші постулати. На цих принципах формується система державної влади в Україні, підвалини демократизму, правила регулюючого впливу права. Загальні ідеї існують об'єктивно, тобто право йде від них. Щодо спеціальних принципів, то вони є продуктом людської діяльності, a їх виникнення пов'язано із формуванням, укоріненням та розвитком правового регулювання в конкретній сфері суспільного буття. Спеціальні принципи формуються поряд із загальними, але під їх впливом, та відображають існуючий правовий порядок у вже сформованому державному юридичному полі.

В аспекті діяльності митних органів за досліджуваним напрямом роботи принципи набувають певної специфіки. Так, принципи забезпечення прав громадян митними органами України - це вихідні, об'єктивні, закономірні положення, керівні ідеї правової діяльності Державної митної служби України в сфері дотримання, забезпечення реалізації та захисту прав громадянина та людини в рамках здійснення митної справи. Розглядаючи ці принципи, необхідно зауважити про їх структурованість. Так, правове забезпечення прав громадян у діяльності митних органів $€$ нестандартним напрямом їх функціонування, який має власне коло правових засад, специфіку, особливості. В зв'язку із цим принципи, на яких він грунтується, являють собою симбіотичне поєднання загальних принципів права, а також керівних ідей діяльності митних органів, митної справи тощо.

Так, якщо ми кажемо про загальноправові принципи, то необхідно зауважити, що вони пронизують усі правові норми, з однаковою силою діють у всіх галузях права незалежно від характеру та специфіки регульованих ними суспільних відносин, будучи стрижнем усієї системи національного права. Вони залежать від рівня розвитку суспільства і виступають універсальним критерієм становлення правової системи держави. Загальноправові принципи закріплюються 
в міжнародно-правових документах та Конституції України. До загальноправових принципів найчастіше відносять: принцип справедливості, принцип рівності, принцип гуманізму, принцип демократизму, принцип законності [7, с. 34].

Митна справа в Україні також має ряд власних керівних положень, які перелічено у чинному Митному кодексі нашої держави. Зокрема, відповідно до статті 8 цього законодавчого акту митна справа здійснюється на основі принципів: виняткової юрисдикції України на ії митній території; виняткових повноважень органів доходів і зборів України щодо здійснення митної справи; законності та презумпції невинуватості; єдиного порядку переміщення товарів, транспортних засобів через митний кордон України; спрощення законної торгівлі; визнання рівності та правомірності інтересів усіх суб'єктів господарювання незалежно від форми власності; додержання прав та охоронюваних законом інтересів осіб; заохочення доброчесності, гласності та прозорості; відповідальності всіх учасників відносин, які регулюються Митним кодексом України [8].

У процесі наукового обгрунтування діяльності митних органів теоретики відносять до принципів їх діяльності такі керівні ідеї: принцип законності, принцип виняткової компетенції митних органів України під час здійснення митної справи, принцип об'єктивності, принцип справедливості, принцип незалежності діяльності митних органів, принцип взаємодії митних органів із іншими органами державної влади, принцип рівності сторін, принцип додержання прав та охоронюваних законом інтересів фізичних та юридичних осіб, принцип гуманізму, принцип гласності та прозорості тощо [9, с. 89-90].

Отже, на законодавчому рівні та у правовому полі є велика кількість принципів, пов'язаних із митною справою, діяльністю митних органів або правовим регулювання суспільних відносин в країні загалом. У кожному разі йдеться про окремі групи правових принципів. На нашу думку, принципи забезпечення прав громадян митними органами України також необхідно розглядати як окрему групу керівних ідей. Спираючись на вищенаведене та враховуючи сутнісні особливості роботи митних органів у досліджуваному напряму, ми переконані, що вказані принципи включають в себе:

1) Принцип верховенства права. Зазначений принцип походить від статті 8 Конституції України, в якій вказано: «В Україні визнається і діє принцип верховенства права. Конституція України має найвищу юридичну силу. Закони та інші нормативно-правові акти приймаються на основі Конституції України і повинні відповідати їй. Норми Конституції України $є$ нормами прямої дії. Звернення до суду для захисту конституційних прав і свобод людини і громадянина безпосередньо на підставі Конституції України гарантується» [10]. Натомість зміст цього принципу розкривається у іншому положенні офіційного акту, а саме Рішенні Конституційного Суду України у справі за конституційним поданням Верховного Суду України щодо відповідності Конституції України (конституційності) положенням статті 69 Кримінального кодексу України (справа про призначення судом більш м’якого покарання) від 2 листопада 2004 р. № 15-рп/2004, в якому зазначається, що верховенство права - це панування права в суспільстві. Верховенство права вимагає від держави його втілення у правотворчу та правозастосовну діяльність, зокрема у закони, які за своїм змістом мають бути проникнуті передусім ідеями соціальної справедливості, свободи, рівності тощо. Справедливість - одна з основних засад права, яка є вирішальною у визначенні його як регулятора суспільних відносин, одним із загальнолюдських вимірів права. Зазвичай справедливість розглядають як властивість права, виражену, зокрема, в рівному юридичному масштабі поведінки й у пропорційності юридичної відповідальності вчиненому правопорушенню [11]. Отже, відповідно до наведеного принципу забезпечення прав, свобод та законних інтересів громадян у діяльності Державної митної служби України повинно здійснюватися винятково на підставі права та допустимих з погляду останнього методів, засобів та способів.

2) Принцип законності. Із принципом верховенства права перекликається інша важлива загальна ідея національної юридичної реальності - законність. На думку Г.П. Середи, законність - це складне соціальне явище, воно залежить від цілеспрямованої діяльності держави, інститутів громадянського суспільства, від укоріненої у свідомості громадян звички до законослухняної поведінки. Законність - результат діяльності всіх органів держави, суспільства загалом, де прокурорському нагляду належить, на жаль, далеко не провідне місце [12, с. 13]. На думку Л.В. Мелеха, законність - це стан суспільного життя, який характеризується неухильним дотриманням і виконанням законів усіма суб'єктами. Якщо закон закріплює загальнообов'язкові правила поведінки, то законність забезпечує повне і безперешкодне їх здійснення, тобто $\epsilon$ неодмінною умовою реального втілення в життя законів. Отже, дотримання законів забезпечує встановлення законності в суспільстві, а законність - їх реалізацію. Принцип за- 
конності є одним із принципів сучасної концепції правової держави [13, с. 9]. В Конституції України прямої вказівки на принцип законності не передбачено, натомість у статті 19 Основного закону зазначено, що правовий порядок в Україні грунтується на засадах, відповідно до яких ніхто не може бути примушений робити те, що не передбачено законодавством. Органи державної влади та органи місцевого самоврядування, їх посадові особи зобов'язані діяти лише на підставі, в межах повноважень та у спосіб, що передбачені Конституцією та законами України [10]. Відповідно до цього, а також загального уявлення про сутність принципу законності, остання в діяльності Державної митної служби щодо забезпечення прав громадян виражається у неухильному дотриманні службовцями цієї організації вимог та норм чинного законодавства в аспекті забезпечення прав і законних інтересів громадян та людини загалом.

3) Принцип рівності та недискримінації. Цей принцип втілено в багатьох положеннях чинного законодавства та Конституції. Відповідно до нього будь-якій людині та громадянину гарантується рівність перед законом та державою, а також неприпустимість обмеження прав за особистими ознаками, як-от: колір шкіри, віра, стать, релігійні переконання тощо. В контексті роботи Державної митної служби України, зокрема із забезпечення прав громадян, принцип рівності та недискримінації становить гарантію того, що забезпечуватись будуть права всіх без винятку громадян незалежно від їх суб'єктивних ознак.

4) Принцип гуманізму. Гуманізм $є$ фундаментальною основою організації державної влади. Він має загальне значення для устрою всієї держави. Цей принцип означає визнання цінності людини як особистості, затвердження пріоритету ії інтересів у діяльності держави. Гуманізм - це орієнтація на приватні інтереси, на права і свободи людини як вищу цінність [14, с. 30]. У межах роботи митних органів цей принцип виражається у чіткій вимозі щодо поважливого ставлення до честі і гідності людини та громадянина, а також неможливості їх порушення.

5) Принцип взаємодії. Термін «взаємодія» характеризує погоджену діяльність різних суб'єктів, які здійснюють спільні дії. Категорія взаємодії є філософською та відображає процеси впливу об'єктів один на одного, їх взаємну зумовленість і породження одним об'єктом іншого. Погодженість як основна, необхідна ознака взаємодії докорінно впливає на спільні дії, поєднуючи їх у цілісну систему [15, с. 107]. Відповідно до Постанови Кабінету Міністрів України «Про затвердження положень про Державну податкову службу України та Державну митну службу України» від 06.03.2019 №227 Держмитслужба під час виконання покладених на неї завдань, у тому числі в рамках забезпечення прав громадян, взаємодіє з іншими органами виконавчої влади, консультативними, дорадчими та іншими допоміжними органами, органами місцевого самоврядування, громадськими об'єднаннями, відповідними органами іноземних держав і міжнародних організацій та об'єднань, а також підприємствами, установами та організаціями, всеукраїнськими об'єднаннями профспілок і всеукраїнськими об'єднаннями організацій роботодавців [16].

6) Принцип гласності та прозорості. Так, прозорість і гласність - це одні з найважливіших проявів демократичності держави, основа демократії, іiі фундамент, оскільки тільки інформованість громадян надає їм можливість із знанням справи брати участь в управлінні державою. Ці аспекти виступають як гаранти права на свободу слова, на свободу переконань і вільне ïx вираження [17, с. 3]. Діяльність митних органів із забезпечення прав громадян відповідно до цього принципу має бути відкритою, митні органи інформують громадськість щодо процесу іiі реалізації та наслідки.

Висновки. У підсумку представленого дослідження відзначимо, що саме так виглядає коло ключових принципів забезпечення прав громадян в діяльності митних органів України. Кожен 3 них несе в собі керівне начало правового регулювання у цій сфері. В сукупності вони становлять консолідовану ідею, відповідно до якої будується робота Державної митної служби України в аспекті дотримання та захисту основних інтересів громадян та людини загалом, надання можливості реалізовувати їх у контексті митних відносин.

\section{Список використаних джерел:}

1. Даль В. Толковый словарь живого великорусского языка. Москва, 1980. Т. 3. 555c .

2. Кириленко Г.Г., Шевцов Е.В. Краткий философский словарь. Москва : АСТ, Слово, 2010. $480 \mathrm{c}$.

3. Лившиц Р.3. Теория права. Москва : Издательство БЕК. 1994.

4. Семенова И.С. Принцип равенства перед законом в уголовном праве Российской Федерации: диссертация. Саратов : Саратовский юридический институт. 2004. 184 с.

5. Теория государства и права / Под. ред. А.М. Васильева. Москва : Юрид. лит., 1977. 472 с. 
6. Коваль О.А. Принципи процесуального права та їх втілення в законодавчій регламентації діяльності міліції України: дисертація. Київ : Київський національний університет внутрішніх справ. 2005. 198 с.

7. Мельник К.Ю. Трудове право України : підручник. Харків : Діса плюс, 2014. 480 с.

8. Митний кодекс України: кодекс, закон від 13.03.2012 №4495-VI. Відомості Верховної Ради України. 2012. №44-45. ст.1858.

9. Комзюк В.Т. Завдання та принципи діяльності митних органів України та спеціалізованих митних установ. Право і Безпека. 2012. № 1. С. 86-90.

10. Конституція України: конституція, закон від 28.06.1996 №254к/96-ВР. Офіиійний вісник Украӥни. 2010. №72/1. Ст. 2598.

11. Рішення Конституційного Суду України у справі за конституційним зверненням Київської міської ради професійних спілок щодо офіційного тлумачення частини третьої статті 21 Кодексу законів про працю України (справа про тлумачення терміну «законодавство») : від 9 лип. 1998 р. : Справа № 12-рп/98. Офіиійний вісник Украӥни. 1998. № 32. стор. 59.

12. Середа Г. Законність оперативно-розшукової діяльності як мета та завдання прокурорського нагляду. Вісник Наџіональної академії прокуратури України. 2009. № 4(16). С. 11-17.

13. Мелех Л.В. Законність у правозастосовній діяльності : автореферат. Львів : Львівський державний університет внутрішніх справ. 2010. 22 с.

14. Ладиченко В.В. Гуманістичні основи організації державної влади : автореферат. Київ : Інститут законодавства Верховної Ради України. 2008. 42 с.

15. Кушнір І.П. Правові аспекти взаємодії державної прикордонної служби України з органами виконавчої влади й органами місцевого самоврядування. Часопис Київського університету права. 2006. № 2. С. 106-110.

16. Про затвердження положень про Державну податкову службу України та Державну митну службу України: постанова, положення від 06.03.2019 № 227. Офіційний вісник Украӥни. 2019. № 26. ст. 900.

17. Король В.В. Засада гласності та їі обмеження в кримінальному судочинстві України : автореферат. Київ : Київський національний університет імені Тараса Шевченка. 2002. 22 с. 